\title{
The Awareness of Locals in Culture Tourism: The Sample of Sille/Konya
}

\author{
Şebnem Ertaş ${ }^{1}$, Elif Sönmez ${ }^{1}$, Alper Torun ${ }^{1} \&$ Firdevs Kulak Torun ${ }^{2}$ \\ ${ }^{1}$ Department of Interior Architecture, Karadeniz Technical University, Trabzon, Turkey \\ ${ }^{2}$ Department of Interior Architecture, Mimar Sinan Fine Arts University, Istanbul, Turkey \\ Correspondence: Şebnem Ertaş, Department of Interior Architecture, Karadeniz Technical University, Trabzon \\ 61080, Turkey. Tel: 90-536-418-1980. E-mail: sebnemarc@hotmail.com
}

Received: January 14, 2017

doi:10.5539/jsd.v10n2p125
Accepted: February 2, 2017 Online Published: March 30, 2017

URL: https://doi.org/10.5539/jsd.v10n2p125

\begin{abstract}
One of the important aspects affecting the development of tourism is the perspective of locals and their reaction about the tourism. In the study, the opinions of locals were received about their perception for tourism and their participation trend to tourism activities in the settlement of Sille which is in an important culture tourism region connected to Konya. The data obtained by on-site survey method through 75 samples were analyzed .In consequence of the research; it is possible to say that Sille which is located in an important region of Turkey in terms of culture tourism has the suitable potential for alternative tourism and recreation with historical and cultural features of it and the economic effects of tourism are perceived in a more positive way by the locals.
\end{abstract}

Keywords: culture tourism, sustainable tourism, locals, sille/konya

\section{Introduction}

The changes in the scope of tourism occurred depending on the different needs and desires of people as a result of social, economic and technological changes experienced in the globalizing world (Soykan, 2003). Preferring the original and different attractiveness by the people outside the usual activities instead of choosing the holiday types in the composition of sea-sand-sun became effective in this change. As a result of this, some tourism types such as special interest tourism, rural tourism, eco-tourism and cultural tourism arisen in addition to physical activity tourism activities as recreation, entertainment, health, sports. Especially in the recent years, it is possible to say that the culture is the biggest factor for the people to take a trip (Özdamar, 2011).

The Cultural tourism is described as; a type of trip that contains natural areas, monumental or civil architecture structures, works of art, collections, cultural identities, traditions, and languages and purposes to share and know all products of intangible and tangible cultural heritage (ÇEKÜL, 2012). In this context, the richness and diversity of nature, history and culture hosted by Anatolian geography take Turkey to the status of an assertive presenter in cultural tourism. While cultural tourism includes important opportunities for protecting and keeping our country's cultural heritage alive, it also proposes some items for the agenda such as new investment and business opportunities especially for small-scale historic towns, options increasing the economic development and competitiveness (ÇEKÜL, 2012).

In the world; San Gimignano that is the settlement of 12th and 13th century in Toscana region in Italy, Sacromonte and Albaicin regions in Granada/Spain are the samples of historic settlements developing together with the tourism by adhering to the principles of protecting and keeping alive (Figure 1). 


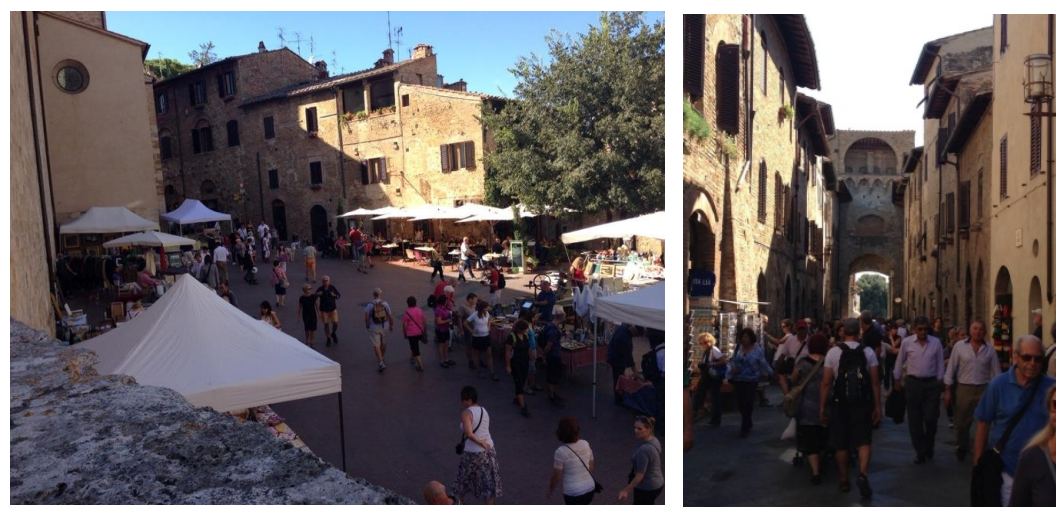

Figure 1. San Gimignano, Italy, (Ertaş, 2013)

In Turkey, Safranbolu and Beypazari are some of the important samples. In the same way, Cumalikizik village that includes the examples of early life countryside civil architecture of Ottomans as a district of Bursa and Odunpazarı of Eskişehir can be shown among the settlements which have these characteristics (Figure 2).
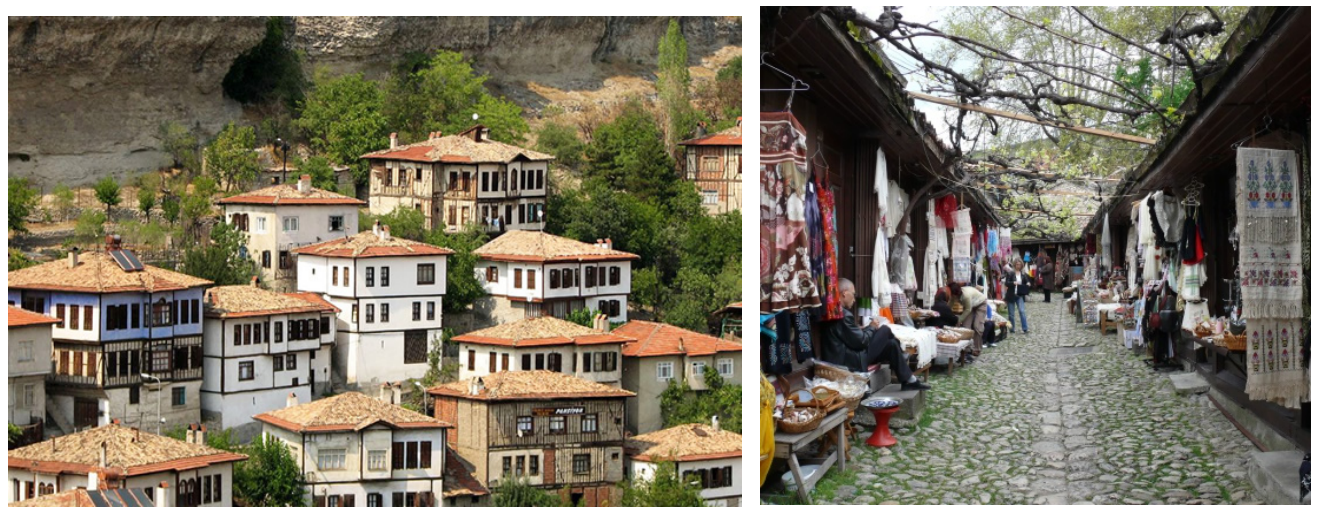

Figure 2. Safranbolu, Turkey, (URL-5)

Tourism should pay dividends to the host community, provide opportunities to them in order to protect and maintain their cultural heritages and cultural traditions and motivate them in this way (International Cultural Tourism Regulation 1999). According to World Trade Organization (WTO), the sustainable tourism is; a resource management where the future opportunities are protected and developed and the needs of today's tourists and host countries are satisfied. Under the favor of this resource management, the continuance of cultural integrity, ecological process and biological diversity is provided and socio-economic and aesthetic needs are satisfied (TÜSİAD, 2012). Tosun and Timothy (2003), in their study, pointed that community involvement has a vital importance in tourism development policies and strategies. According to the researchers, the perception of "community-based-oriented tourism" is forming the basis of sustainability of tourism with all aspects (social, economic and environmental) (Bilim \& Özer, 2013).

The success and competitiveness of a tourism region highly depend on the power and diversity of the indigenous touristic items presented for the visitors (Cracolici \& Nijkamp, 2008; Eser et al., 2010). Producing the community-oriented employment opportunities should also be predicted with local ownership. Thus, the necessity that the settlement should be supported with the factor of user excluding architecture and urban fiction was revealed. Recreation activities take the shape according to the identity of the user. The users have an important role in shaping the recreative areas and emerging of potential. Thus, there has occurred a necessity that the studies carried out about the tourism approaches of users participated in planning phase directly should be performed for all areas related to tourism. One of the most important dimensions of multidimensional sustainability policies and strategies is based on the participation of locals and use of local systems (Ertuna et al, 2012). In this context, first thing to do is (for making the planning accurately and understandably and making it sustainable) the expansion of the question that how the locals perceive the tourism and what they expect from it? 
(Alaeddinoğlu, 2007; (Bilim \& Özer, 2013). In planned studies carried out for providing the favor for locals in social, cultural, economic, environmental and political terms, the participation of locals to planning should be promoted and there should also be provided for them to peg down how kind of development about tourism they want. However, in case this participation is provided, "the development of tourism will reflect what the people want commonly" (Yüksel, 2004; Bilim \& Özer, 2013).

In this study, there was departed from the idea of necessity that locals who are the important users should participate in tourism intentional studies in order to provide the sustainability in tourism. The study was carried out in the settlement of Sille connected to Konya where the tourism activities have not gained intensity yet but that has a big potential in this was and which is in an important tourism region in Turkey. Sille, which is a very rich settlement in terms of history and culture, is an important region, which has lived with these values to our day and which continues to preserve its social life at present like in the past (Ertaş et al., 2016). Sille is remarkable as an important cultural valley, as one of the rare settlements that allow different beliefs and cultures to live in tolerance in the same geography (Kurak Açıc1, 2014). In the study, there was targeted to get the opinions of locals in Sille about the tourism perception of the public and the tendency for participation in tourism activities by determining the tourism potential, tourism types and possible effects of tourism in tourism planning. For this purpose, a survey with nine questions was asked to the locals. Survey questions include about opinions and problems of locals in Sille and before/after of tourism what they can be supports. Therefore, it was thought that locals will be effective for the activities thought to be done in Sille from the beginning and in this context; the appropriate tourism perception for natural and cultural features of the region in planning phase will be developed accordingly.

\subsection{Konya /Sille}

Sille which is located in Central Anatolia region on the northwest of Konya city is far from the city center about $8 \mathrm{~km}$ (Figure 3). Sille is a settlement that has cultural and ethnic diversity in urban fabric with cultural assets consist of mosques, churches, monasteries, baths, bridges, fountains, traditional houses and bond houses belong to Seljuk and Ottoman periods (Aklanoğlu, 2009).

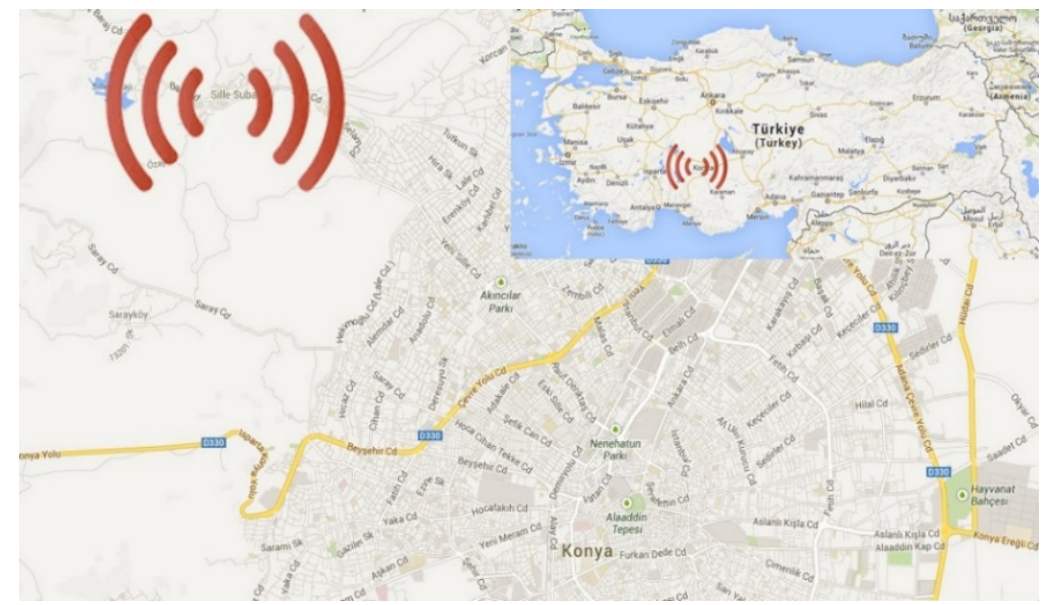

Figure 3. The location of Sille in Turkey and Central Anatolia region (URL-2, 2015)

It has hosted many civilizations especially such as Greek, Seljuk and Ottoman in history about 5000 years. Living Muslim and non-Muslim societies together until today in Sille that is on Silk and Spice routes and accepted as an important trade center caused cultural diversity and the settlement to become a trade center (Erdem et al., 2010).

It is known that 16 villages were connected to Sille where was an advanced and important settlement socioeconomically in some areas especially such as trade, carpet weaving, pottery, viticulture, stonework, candle making, and this location has reached to the population about 18.000.

It is understood that the population was decreased significantly and settlement got serious damages socioeconomically as a result of sending the Greek people to Greece with population exchange because of Treaty of Lausanne signed at earlier stages of republic. Sille has become a district connected to Selcuklu Borough after 1989 while it was an independent municipality previously. The population of Sille decreased until 1500. Although Sille has lost the old socio-economic and cultural values and aliveness of it, it still protects the current 
city identity (Erdem et al., 2010).

Sille which became a host for many buildings since middle ages until the period of Republic is a history and culture valley. The attraction items, mosques, churches, cemeteries, water, roads, bridges, fountains, baths, houses and streets which are some of the original features settlement has in terms of sustainable cultural tourism are important values witnessed the history (Tomar, 2015), (Figure 4).

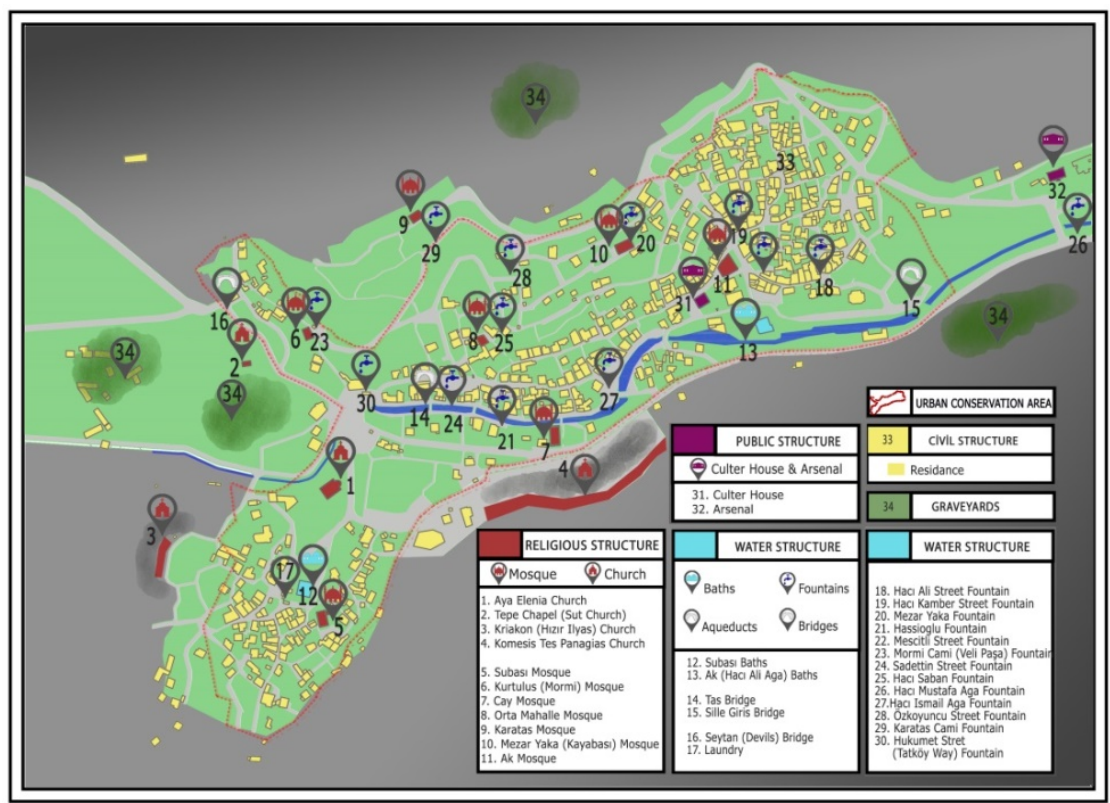

Figure 4. The settlement plan and cultural assets (Ertaş et al., 2016b)

Sille became the focus point for Konya city in tourism either about national or international scale in recent years with the expansion of cultural tourism (Aklanoğlu, 2009), (Figure 5).

The usage of historical buildings started to be shaped for tourism especially at Hukumet Street and around which are the important arteries in Sille. Thus, the study carried out is important as a result of the fact that it reveals the support and participation about the perceptions of locals for the results of tourism.
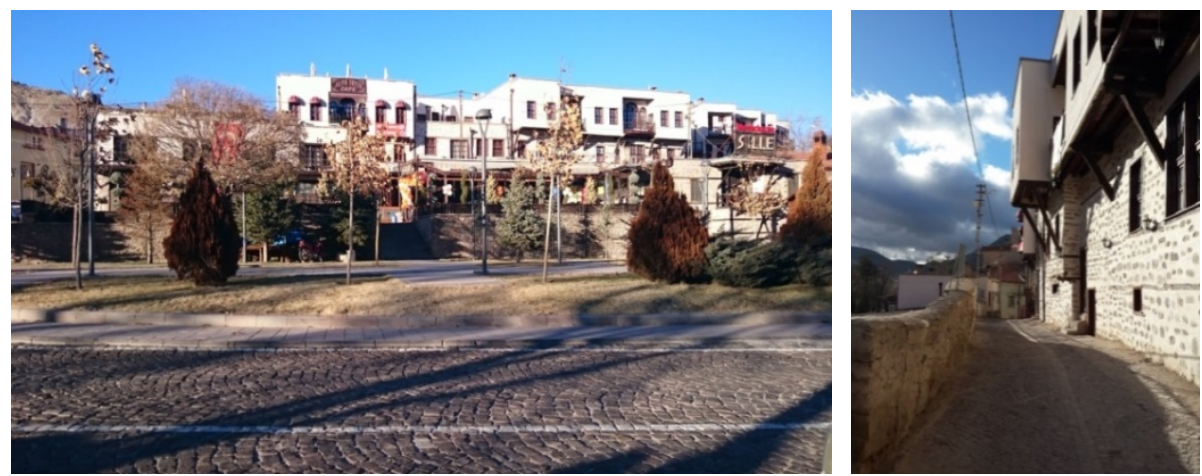

Figure 5. Haci Ali Ağa Street (Personal Archive, 2016)

\section{Method}

In the study, standard forms from quantitative research techniques and site "questionnaire" data collection techniques were used for determining the perceptions of locals of Konya/Sille settlement about tourism.

There was targeted to determine the predictions about the area and ideas of the community about tourism, to reveal the expectations from tourism and contributions to tourism by determining the profile (age, sex, educational features, etc.) of locals with the questionnaire studies carried out intended to locals. In addition to this, the opinions of locals were taken about variables created by tourism in the region, the idea of investing in tourism, the contributions they could give to tourism and the things to be done for the development of tourism in 
order to determine the attitudes. It is thought that this study to be carried out will be an important resource for the plans and projects in developing tourism in Sille.

The sample size formula was used for determining the numbers of visitors (Kalipsiz, 1981). The questions of the questionnaire were asked to 75 individuals chosen by random sampling method among 3780 people determined as the estimated population of the region while the sample was designated. The questionnaire study carried out with face-to-face interview technique; has been performed June-July in the summer period and October-November in winter period.

While the questionnaires for locals are prepared; there was benefited from the research of Kiper (2006). The questionnaire was adapted to Sille in the light of data obtained from the visits to Sille and some expressions were removed and new expressions were added. The method of the multiple-choice proposition was used in questionnaire application.

The data obtained in accordance with the answers of locals were analyzed with SPSS V.22 statistical software package.

\section{Results}

While the tourists participated in questionnaire are evaluated according to their demographic features (Table 1);

- According to their age; between 18-24 years old was about \%16, 25-34 24 years old about \%22,7, 35-44 years old about $\% 21,3,45-54$ years old about $\% 10,7,55-64$ years old about $\% 21,3$ and 65 years old and above was about $\% 8$.

- It can be said that generally, the education level of most of the people participated the questionnaire was high school level.

- $\% 65,3$ of individuals participated in questionnaire were males and $\% 34,7$ of them were females.

- The marital status of individuals participated in questionnaire; $\% 81,3$ were married and $\% 18,7$ were single.

Table 1. Demographic features

\begin{tabular}{|c|c|c|c|}
\hline & & \multicolumn{2}{|c|}{ Locals } \\
\hline & & Frequency & $\%$ \\
\hline \multirow{7}{*}{ Age } & $18-24$ & 12 & 16 \\
\hline & $25-34$ & 17 & 22,7 \\
\hline & $35-44$ & 16 & 21,3 \\
\hline & $45-54$ & 8 & 10,7 \\
\hline & $55-64$ & 16 & 21,3 \\
\hline & $65+$ & 6 & 8,0 \\
\hline & Total & 75 & 100,0 \\
\hline \multirow{3}{*}{ Gender } & Male & 49 & 65,3 \\
\hline & Female & 26 & 34,7 \\
\hline & Total & 75 & 100,0 \\
\hline \multirow{6}{*}{ Education } & Literate & 15 & 20,0 \\
\hline & Primary school & 15 & 20,0 \\
\hline & High school & 31 & 41,3 \\
\hline & Associate & 9 & 12,0 \\
\hline & Graduate & 5 & 6,7 \\
\hline & Total & 75 & 100,0 \\
\hline \multirow{3}{*}{ Marital Status } & Single & 14 & 18,7 \\
\hline & Married & 61 & 81,3 \\
\hline & Total & 75 & 100,0 \\
\hline
\end{tabular}


While profession groups are considered, $\% 10,7$ of the people participated the questionnaire specified that they were farmer, $\% 13,3$ of them were artisan-merchant, $\% 10,7$ of them were dealing with tourism, $\% 8$ of them were in public institutions, 16 of them were housewives, $\% 20$ of them were retired, $\% 4$ of them were temporarily unemployed, $\% 18,7$ of them were workers and $\% 4$ of them were students.

While the distribution of original features for Sille is examined, it is thought that some of the leading rustic features are traditional architecture, rural texture and historical and cultural values. The local food, traditional handiworks, agricultural structures and regional products, vegetation and winemaking are following these features respectively (Table 2).

Table 2. The features which the locals finds specific to Sille

\begin{tabular}{lcc}
\hline & \multicolumn{2}{c}{ Locals } \\
\hline & Frequency & $\%$ \\
\hline Traditional architecture with rural texture (Historical houses, streets etc.) & 66 & $\mathbf{8 8 , 0}$ \\
Agricultural structures and regional products (Fruits and vegetables, & 19 & 25,3 \\
vineyards and orchards etc.) & 7 & 9,3 \\
Vegetation & 64 & 85,3 \\
Historical and cultural values & 27 & 36,0 \\
Traditional handicrafts & 7 & 9,3 \\
Winemaking & 34 & 45,3 \\
Local food & - & - \\
Other & & \\
\hline
\end{tabular}

According to locals, the unemployment with the ratio of $\% 81,3$ is coming at the top of the most important problems seen in Sille. There is also specified that young labor force is scarcely any and investments are also less at the same rate. These facts have been revealed by the locals in the results of questionnaires as the economic difficulties. Migration from the country to town is also another problem as the previous ones. While the reasons for returning to Sille for the people migrated from their families, it is seen that $\% 92$ of these people participated in the questionnaire gave the answer as they came to visit their relatives. Apart from that, most of these people said that they use their houses in the village at weekends and $\% 20$ of them specified that they came for working in a touristic institution.

The people participated in questionnaire said about the changes which will be created in the region by the development of tourism in Sille that the village will develop much better accordingly. In parallel to this, a significant rate of people specified that tourism will create new business spaces, increase the income level of locals and young labor force will be brought back to the village accordingly (Table 3). 
Table 3. The evaluation of locals about the changes on region created by tourism

\begin{tabular}{lcc}
\hline & \multicolumn{2}{c}{ Locals } \\
\hline & Frequency & $\%$ \\
\hline I do not think so, it does not create & 70 & $\mathbf{9 3 , 3}$ \\
The village develops in a better way & 7 & 9,3 \\
It becomes an alternative source of income for locals by increasing & & 56,0 \\
agricultural production & 42 & 53,3 \\
The level of income of locals increases. & 40 & 69,3 \\
The young labor is regained for the village & 52 & 10,7 \\
It creates new business spaces & 8 & 12,0 \\
It creates opportunities for developing the infrastructure facilities & 9 & 34,7 \\
It creates opportunities for developing the superstructure possibilities & 26 & 26,7 \\
It provides the protection for historical and cultural values & & 20 \\
It prevents the contamination of natural resources by increasing & the & 20 \\
awareness of environmental protection & 16 & 21,3 \\
It ensures the increasing of investment & 11 & 14,7 \\
It provides increased financial support & - & - \\
Other
\end{tabular}

The people participated in questionnaire said the festivals can be organized and emphasized the necessity of organizing the tourism activities in their answers about the activities which are possible to be carried out in Sille. On the other hand, creating the visit and accommodation opportunities in the houses have traditional architecture is also shown as an important activity (Table 4).

Table 4. The evaluation of locals about how kind of activities can be done for tourism in Sille

\begin{tabular}{lcc}
\hline & \multicolumn{2}{c}{ Locals } \\
\hline & Frequency & $\%$ \\
\hline To visit and stay in traditional architectural house & 42 & $\mathbf{5 6 , 0}$ \\
To organize the trip in agricultural land and collect the vegetables, fruits & 13 & 17,3 \\
etc. & 53 & 70,7 \\
To organize festivals & 27 & 36,0 \\
Exhibition of handicrafts & 47 & $\mathbf{6 2 , 7}$ \\
To organize tourist activities (hiking, bicycle tours, trekking etc.) & - & - \\
Other & & \multicolumn{2}{c}{} \\
\hline
\end{tabular}

The locals specified that they could provide serving and guidance services for domestic and foreign visitors and they could support the tourism studies accordingly. They also specified that the attention of visitors can be attracted by handicrafts and also different services can be provided by the use of traditional houses for accommodation (Table 5). 
Table 5. The evaluation of locals about the services which they can support the tourism studies with

\begin{tabular}{lcc}
\hline & \multicolumn{2}{c}{ Locals } \\
\hline & 8 & 10,7 \\
\hline I cannot give any support & 31 & $\mathbf{4 1 , 3}$ \\
I can help bringing the traditional architecture tissue to tourism for housing & & \\
purposes & 19 & 25,3 \\
I can provide the usage of traditional agricultural products kinds of foods in \\
tourism
\end{tabular}

The people participated in questionnaire specified in the proposition studies about how can the migrants give support to the studies for tourism in the rate of $\% 41,3$ that migrants can give serving and guidance services to the visitors. In addition, the food types, handiworks and guesthouse works are following these facts respectively.

The most important activity in order to develop the tourism thought by the locals participated in questionnaire is; concentrating on publicity. The locals especially think that the number of festivals and carnivals performed in the region should be increased and tourism education program should be prepared for locals and workers in the region. While the other activities are considered, there is seen that it is necessary to establish an association to organize the tourism. As a result of establishing such an association, the coordination among the private institutions will be provided and more effective solutions will be created accordingly for some cases such as satisfying the expectations of customers in a better way, increasing the service quality and finding the solutions for the problems about tourism etc. (Table 6).

Table 6. The evaluations of locals about what to do in order t-o develop the tourism in Sille

\begin{tabular}{lcc}
\hline & \multicolumn{2}{c}{ Locals } \\
\hline & Frequency & $\%$ \\
\hline To focus on advertisement & 56 & $\mathbf{7 4 , 7}$ \\
To constitute an association for organizing tourism & 21 & 28,0 \\
To prepare an education program for local community and local employee & 26 & 34,7 \\
To finance public and private organizations making infrastructure and & 11 & 14,7 \\
superstructure for tourism & & 13,3 \\
To increase restoration attempts & 20 & 26,7 \\
To improve service quality & 12 & 16,0 \\
To supply coordination in between public and private organizations to & & \\
develop tourism & 16 & 21,3 \\
To increase of tourist accommodation with working together travel & & \\
agencies & 45 & $\mathbf{6 0 , 0}$ \\
To increase festivals & - & - \\
Other & & \\
\hline
\end{tabular}

\section{Discussion and Conclusion}

Sille located in developing tourism region in Turkey and has original architecture and carries value in terms of 
alternative tourism with rich historical and cultural structure is a place that can provide opportunities for diversifying and spreading of tourism through the year as an alternative to the city center of Konya in the region. This situation shows parallelism with national tourism policy and objectives of the World Tourism Organization.

The Opinions and suggestions of locals have a place in reaching the versatile information needed about the regions which have typical values in the diversification of tourism and knowing the effects of tourism over the local economy that will make tourism more effective, in protecting the environmental factors feeding the tourism and describing these factors in detail. Thus, the participation of locals should be provided in all studies carried out about tourism.

A lot of studies are being done in Sille for opening the cultural areas to tourism. Today's tourism activities carried out in the region are also supporting the cultural tourism. The findings are generally showing that locals want to participate in a possible rural tourism activity and also their perception of the results of tourism. One of the expectations of locals is the contribution of tourism for preventing emigration as a result of the fact that tourism revives the economy of the region with its activities. There was specified that the developments about sustainable tourism can contribute positively to the unemployment that is seen as the biggest trouble in the area of research and the region can develop accordingly. The people living in the study area specified that traditional architecture structures can be used for accommodation.

The diversification of limited sources of livelihood is important in Sille. Handiworks and trade that can support the tourism sector are seen as the alternative working areas for tourism by the community. The development of the sectors which could support the tourism should be supported for ensuring continuity of income coming from tourism and expanding this income to a widespread base. The approach of use of local values in tourism is among the attractive factors for high-income tourists who are looking for different tastes in recent years. The people who live in the study area are aware of the situation and they specify that the local values should be used for developing tourism in the region.

The opinions of locals have been revealed with this study about the development and effects of tourism activities in settlement. Presenting the opinions by the community about tourism is an important data in order to solve the possible future problems. This kind of researches includes important information for relevant institutions and organizations as well as especially for local administrations.

In conclusion, Sille located in an important region of Turkey in terms of cultural tourism has the appropriate potential for alternative tourism and recreation with its historical and cultural features. Benefiting from these features of Sille by taking care of protection-usage balance will contribute the tourism diversification and spreading it to different seasons for the city of Konya. Moreover, it is necessary for the future to repeat this and similar studies periodically in order to see the development of cultural tourism in settlement place.

\section{Acknowledgments}

"This work was supported by TUBITAK (The scientific and technological research and council of Turkey, Grant Number: 114K599). Thank you to the entire team working on the project at TUBITAK."

\section{References}

Aklanoğlu, F. (2009). Geleneksel Yerleşmelerin Sürdürülebilirliği ve Ekolojik Tasarım: Konya-Sille Örneği. Postgraduate Thesis, Ankara University, Physical Sciences Institute, Ankara.

Alaeddinoglu, F. (2007). Van Halkının Turisti ve Turizmi Algılama Şekli. Journal of Geographical Sciences, $5(1), 1-16$

Bilim, Y., \& Ozer, O. (2013). Yerel Halk Gözüyle Konya'da Turizmin Önemi ve Ekonomik, Sosyal, Çevresel Etkileri. National KOP Regional Development Symposium, Konya. Retrieved from http://unikop.org/makale/KS13-4-08.pdf

ÇEKUL Vakfı, Tarihi Kentler Birliği. (2012). Sürdürülebilir Kültür Turizmi İ̧̧in Kamu-Yerel-Sivil-Özel İşbirliği. Ebat Ofset, Gaziantep. Retrieved from http://library.atilim.edu.tr/shares/library/files/e-kitap/SürdürülebilirKültürrTurizmi_2012-Ekitap.pdf

Cracolici, M. F., \& Nijkamp, P. (2008). The Attractiveness and Competitiveness of Tourist Destinations: A Study of Southern Italian Regions. Tourism Management, 30, 336-344. https://doi.org/10.1016/j.tourman.2008.07.006

Erdem, R., Yıldırım H., Çiftçi Ç., Dülgerler O. N., Çıbıkdiken A. O., Levend S., \& Erdoğan A. (2010). Koruma Geliştirme Planı ve Sonrası. J. Fac.Eng.Arch. Selcuk Univ., 25(2), 25-46. 
Ertaş, Ş., Kulak Torun F., Taş A., \& Torun A. (2016b). Cultural Property With Touristic Potential: Example Of Sille, 2nd ICNTAD'16, International Conference on New Trends in Architecture and Interior Design, 19-22 April, Zagreb, 175-185.

Ertaş, S., Sönmez E., Sadıklar Z., \& Kafil P. (2016a). History Through Image and Symbol: Konya/Sille, 2nd ICNTAD'16, International Conference on New Trends in Architecture and Interior Design, 19-22 April, Zagreb, 167-174.

Ertuna, B., Güney, S., Güven, Ö., \& Aydemir, N. (2012). Factors Influencing Residents' Willingness to Participate in Rural Tourism Development: The Case of Kastamonu. International Journal of Social and Economic Sciences, 2(2), 59-66.

Eser, S., Dalgin, T., \& Ceken, H. (2010). Sürdürülebilir Kültür Turizmi: Efes Örneği. Aegean Geographical Journal, 19(2), 27-34, İzmir.

International Cultural Tourism Regulation. (1999). Tourism management in the areas has the cultural heritage value, Translation: $\quad$ Z $\quad$ Ahunbay, 2011. Retrieved from http://www.icomos.org.tr/Dosyalar/ICOMOSTR_0473172001407841550.pdf

Kalıpsız, A. (1981). Istatistik Yöntemler, Istanbul University Faculty of Forestry Publications, Istanbul University, Publication No.2387 Istanbul.

Kiper, T. (2006). Safranbolu Yörükköyü Peyzaj Potansiyelinin Kırsal Turizm Açısından Değerlendirilmesi. Phd Thesis, Institute of Science and Technology, Ankara.

Kurak Açıc1, F. (2014). Mimarlık Tarihi ve Dokusu İçinde Sille, Erdoğan, E. (editör), Sille Düşleri Imgeler-Semboller-İzler, 47-62, Konya.

Ozdamar, M. (2011). Şanlıurfa"da Kültür Turizmi: Şanlıurfa"ya Kültür Turizmi Kapsamında Seyahat Acentaları ile Gelen Yerli Turistlerin Profilini ve İçtepisel Satın Alma Davranışlarını Belirlemeye Yönelik Bir Araştırma. Master Thesis, Social Sciences Institute, Mersin.

Soykan, F. (2003). Kırsal Turizm ve Türkiye için Önemi. Aegean Geographical Journal, 12, 1-11.

Tomar, E. Z. (2015). Sille Koruma Amaçlı Plan Raporu. Seljuk Municipality, Konya.

Tosun, C., \& Timothy, D. J. (2003). Arguments for Community Participation in the Tourism Development Process. The Journal of Tourlsm Studies, 14(2).

TUSIAD. (2012). Sürdürülebilir Turizm, Istanbul. Retrieved from http://www.tusiad.org.tr/_rsc/shared/file/Surdurulebilir Turizm-rapor.pdf.

URL-1. (2016). http://www.seyirrehberi.com/tatil-yerleri.aspx?tatil-yeri=safranbolu

URL-2. (2015). http://maps.google.com/

Yüksel, F. (2004). Turizmde Planlama ve Uygulama: Başarısızlık Nedenleri ve Öneriler, Turizm: İlkeler ve Yönetimi, (Eds.) Atila Yüksel \& Murat Hançer, Turhan Kitabevi (Turhan Bookstore). Ankara, p.103-108.

\section{Copyrights}

Copyright for this article is retained by the author(s), with first publication rights granted to the journal.

This is an open-access article distributed under the terms and conditions of the Creative Commons Attribution license (http://creativecommons.org/licenses/by/4.0/). 